\title{
Engineering biodiversity as a model for the species conservation*
}

\section{ELIBIO L. RECH}

EMBRAPA Genetic Resources and Biotechnology, Laboratory of Synthetic Biology and National Institute of Science and Technology on Synthetic Biology, Parque Estação Biológica, W-5 Norte, 70770-917 Brasília, DF, Brazil

Manuscript received on May 17, 2019; accepted for publication on August 25, 2019

How to cite: RECH EL. 2019. Engineering biodiversity as a model for the species conservation. An Acad Bras Cienc 91: e20190568. DOI 10.1590/0001-3765201920190568.

\begin{abstract}
Early humans have domesticated plant and animal species based on ancient empirical concepts (Darwin 1868, 1876). In 1886, Mendel established a new paradigm of hereditary laws (Mendel 1866, $1870,1950)$ based on genotypic and phenotypic traits of cross-compatible species, establishing a complex breeding technology that is currently utilized for the development of most food and livestock-derived products. Recently, studies on deciphering the double-helical structure (Watson and Crick 1953a, b) and how to restrict DNA (Arber 2012) have established the foundation of recombinant DNA technology. A new era is paving the way for genetic manipulation of important traits among all the kingdom's organisms, allowing for the development of innovative and widely utilized products for the agricultural, industrial and pharmaceutical production sectors (Mc Elroy 2003, 2004, ISAAA 2016).
\end{abstract}

Key words: Biodiversity, Species conservation, DNA, Genetic engineering.

\section{INTRODUCTION}

Brazil has a significant percentage of the economic matrix generated in agribusiness and also constitutes a region of mega-biodiversity. Where conservation and sustainable use of biodiversity is the physical basis for agribusiness, exerted through water resources, water availability, genetic resources, soil conservation, climate stability, and nutrient recycling, among other physical factors and chemicals.

The Amazon region is home to a megabiodiversity (Soares et al. 2006). Different models have been proposed (Peres and Terborgh 1995, Schwartzman et al. 2000, Merry et al. 2003,

E-mail: elibio.rech@gmail.com

ORCid: https://orcid.org/0000-0001-8588-0673

*This work is part of the publications Rech and Arber 2013 and Rech 2017
Nepstad et al. 2002, 2006, Soares-Filho et al. 2006, Gullison et al. 2007) with the aim of establishing an active conservation policy, sustainable use and added value for biodiversity. Over the years the Amazon region has been submitted to a vicious circle that involves devastation of the forest and falling employment. There is a hypothesis linking a reduction in deforestation and an increase in governance with the higher employment and income that is associated with development in various processes and products, and this has been extolled as a virtuous development circle (Nepstad et al. 2002). Besides, generating carbon credits has been suggested as a viable development strategy for the region (Nepstad et al. 2006b, Stern 2006). In contrast, it has been demonstrated that recent significant losses of forest and rising incomes can be linked mainly to the expansion of cattle-farming and soy-growing industries (Nepstad et al. 2006b). 
It is accepted that the real value of biodiversity is still unknown and any estimates are speculative. The Amazon region is so complex that it needs studies based on added value as a factor that, in turn, depends on technological advances. Currently, a broad spectrum of technologies associated with recombinant DNA is available, and these permit the collection, manipulation and practical evaluation of many molecules that come from biodiversity.

Early humans have domesticated plant and animal species based on ancient empirical concepts (Darwin1868,1876). In 1886, Mendel established a new paradigm of hereditary laws (Mendel, 1866, $1870,1950)$ based on genotypic and phenotypic traits of cross-compatible species, developing a sophisticated breeding technology utilized for the development of most food and livestock-derived products. Recently, studies on deciphering the double-helical structure (Watson and Crick 1953a, b) and how to restrict DNA (Arber 2012) have established the foundation of recombinant DNA technology. A new era is paving the way for genetic manipulation of important traits among all the kingdom's organisms, allowing for the development of innovative and widely utilized products for the agricultural, industrial and pharmaceutical production sectors (Mc Elroy 2003, 2004, ISAAA 2016).

Currently, it is possible to state that the world has reached the mature stage of recombinant DNA technology, which, in turn, may allow us to envisage the capacity to generate a significant number of novel processes and products for the benefit of human beings and sustainable utilization and conservation of biodiversity and the environment as a whole. One possibility termed "synthetic domestication of useful traits" (Rech and Arber 2013). Although technical issues are still a challenge, the broad potential of progress is accelerating. Nevertheless, ethics and a comprehensive regulatory system ought to be discussed to guarantee deeper and higher standards of deregulation before any product reaches the market.

Currently, available tools and technologies for synthetic domestication of useful traits have opened the door for another breakthrough in scientific progress (Cermak et al. 2011, Doyon et al. 2011, Gibson et al. 2008, Rech and Arber 2013, Cong et al. 2013, Boch et al. 2009, Carlson and Lancto 2016). Making use of genome editing (Boch et al. 2009, Mali et al. 2013, Li et al. 2013, Jiang et al. 2013, Cong et al. 2013, Doudna and Charpentier 2014, Carlson and Lancto 2016), a template founded on molecular synthesis, assembly and synthetic biology (Yu et al. 2006, Gibson et al. 2008, 2010, Annaluru et al. 2014, Hutchison et al. 2016), has allowed for the sustainable prospection and manipulation of innovative traits found in biodiversity. Examples follows here which should fit within the concept of "synthetic domestication of useful traits", through the utilization of recombinant DNA technology and genetic engineering directing the sustainable use of biodiversity.

\section{PRODUCTION OF SYNTHETIC SPIDER FIBRE}

Spider silk fibre has been noted for its unique physical and mechanical properties and recognized as a protein-based nanomaterial (Lewis 2006, Silva and Rech 2013). To this end, the functional genome of different Brazilian spiders' silk glands have been studied, considering evolution and evaluating the potential development of novel biopolymers through synthetic biology (Bittencourt et al. 2010, Prosdocimi et al. 2011). Drawing on genome and transcriptome data, it has become possible to design de novo proteins and produce synthetic spider-like fibres in bacteria. Which, in turn, has led to the development of alternative strategies for the production of synthetic silk proteins using recombinant DNA technology (Teulé et al. 2009, Murad and Rech 2011). A complete procedure for the artificial spinning of fibres made from 
recombinant proteins based on chimeric or native synthetic spider silk-like sequences was developed and produced through genetic engineering in E. coli. The strategy is to build large synthetic spider silklike tandem repeat sequences from small doublestranded monomer DNAs flanked by compatible but non-regenerable restriction sites (Figure 1 and 2).

\section{ENGINEERING SOYBEAN SEEDS AS A SCALABLE PLATFORM TO PRODUCE A MICROBICIDE AGAINST HIV}

There is an urgent need to provide effective anti-HIV microbicides to resource-poor areas worldwide. Some of the most promising microbicide candidates are biotherapeutics targeting viral entry. For availability of biotherapeutics to poorer areas, it is vital to reduce their cost. Cyanovirin-N (CV$\mathrm{N})$, an $11009 \mathrm{Da}$ protein isolated from cultures of the cyanobacterium Nostoc ellipsosporum, is a potent lectin capable of irreversibly inactivating diverse strains of HIV (types 1 and 2) and simian immunodeficiency virus (Boyd et al. 1997). We report the production of biologically active recombinant cyanovirin-N ( $\mathrm{rCV}-\mathrm{N})$, an antiviral protein, in genetically engineered soybean seeds. Pure, biologically active rCV-N was isolated with a yield of $350 \mu \mathrm{g} / \mathrm{g}$ of dry seed weight. rCV-N purified from soya is active in anti-HIV assays, with an EC50 of 0.82-2.7 nM (compared to 0.45$1.8 \mathrm{nM}$ for E. coli-produced CV-N). Standard industrial processing of soya bean seeds to harvest soya bean oil does not diminish the antiviral activity of recovered $\mathrm{rCV}-\mathrm{N}$, allowing the use of industrial soya bean processing to generate both soya bean oil and a recombinant protein for antiHIV microbicide development (O'Keefe et al. 2015). Expression of rCV-N was achieved using specific regulatory sequences within soybean seed tissues (Rech et al. 2008). One of the difficulties in fully evaluating $\mathrm{CV}-\mathrm{N}$ as a microbicide has been the high cost of production. CV-N produced in soybean seeds addresses this critical requirement,

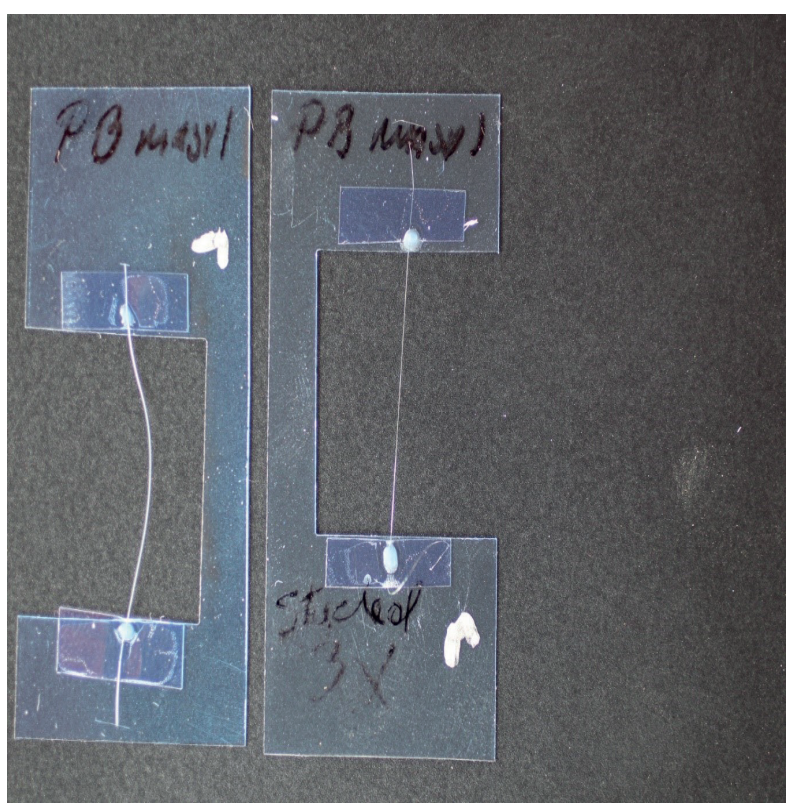

Figure 1 - Parawixia bistriata major ampullate (masp 1) synthetic fibers. (left). Fiber produced by extrusion of a $15 \%$ (wt/vol) MaSp 1 spinning dope; (right) Three times (3X) stretched (Teulé et al. 2009).

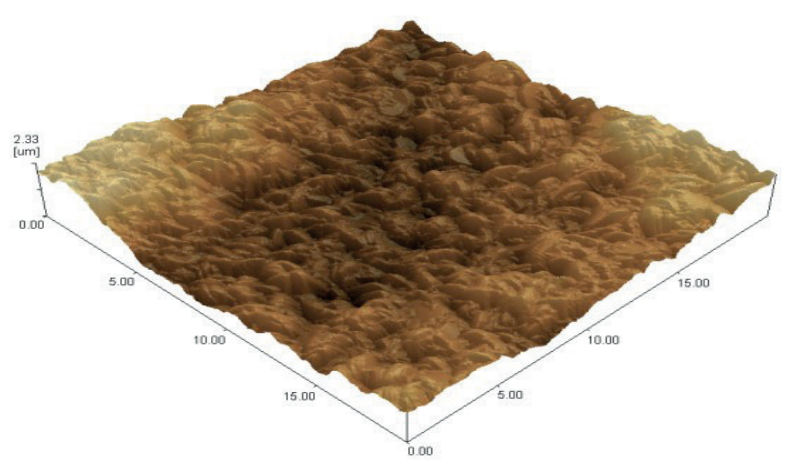

Figure 2 - A representative atomic force microscopy image of the topographic surface of a synthetic spider silk-like fibre made from the synthetic recombinant protein MaSp 2 from Parawixia bistriata.

and soya beans should be evaluated as a production system to produce other suitable candidate microbicides for further preclinical evaluation and, possibly, clinical testing in humans. Development of a suitable expression source for the manufacture of an anti-HIV topical microbicide requires a lowcost methodology to have the broadest utility in the areas of the world most affected by HIV (Essex 
1996, Gartner et al. 1986, O’Keefe et al. 2009). Suitable microbicide candidates must meet an array of criteria. Although potential microbicides meeting some of these functional criteria are available, few microbicides have been able to be produced at sufficiently low cost (Figure 3 ).

\section{REGULATORY GENE CIRCUITS UTILIZING SERINE INTEGRASES}

Although single genetic switches and circuits are in the early stage of development, it is possible to envisage a not-too-distant future in which multiple switches become the norm, allowing increasingly precise control of gene regulation and expression in plants and mammalian cells for the development of innovative processes and products for the benefit of human beings and the environment. Studies on gene regulation have demonstrated effective control of the RNA polymerase flux by utilizing different serine integrases, which are capable of catalysing unidirectional inversion of DNA to turn on/off regulatory genes in prokaryotic cells (Schwille 2011, Nandagopal and Elowitz 2011, Bonnet et al. 2013, Yang et al. 2014, Nielsen et al. 2016, Weinberg et al. 2017). A simplified mathematical model was proposed to explain and define core features that are demanded and sufficient for the regulation of both 'forward' and 'reverse' integrase reactions (Pokhilko et al. 2017). In this model, the substrates of the 'forbidden' reactions (between attL and attR in the absence of RDF and between attP and attB in the presence of RDF) are trapped as inactive protein-DNA complexes, ensuring that these 'forbidden' reactions are prolonged. The model is in good agreement with the observed in vitro kinetics of recombination by $\phi \mathrm{C} 31$ integrase, and it defines the core features of the system that are necessary and sufficient for directionality. However, knowledge about the functionality of integrases in eukaryotic cells is still limited. Here, we show the remarkable functional capability

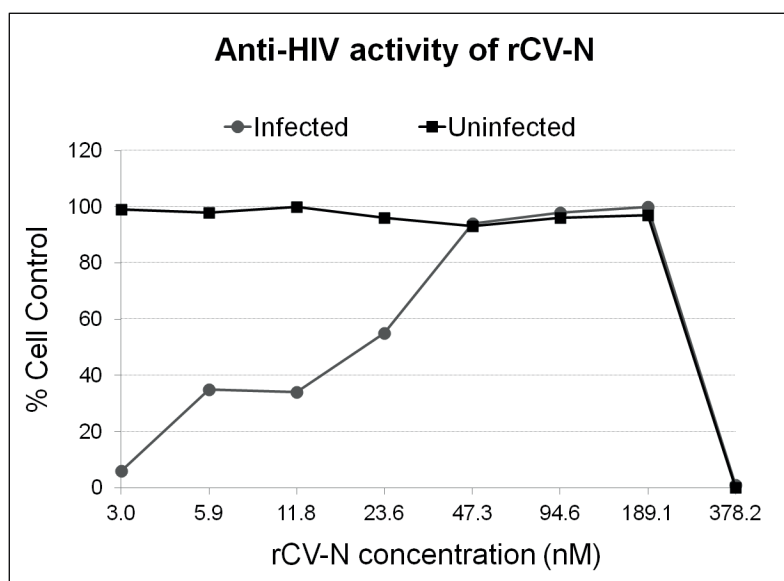

Figure 3 - Concentration dependant anti-HIV activity of

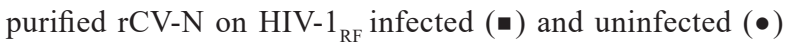
CEM-SS cells assessed after 6 days in culture. The number of surviving cells was measured by the XTT method and is indicated as percent untreated uninfected cell control. Pure rCV-N (infected) had an $\mathrm{EC}_{50}$ value of $20.82 \mathrm{nM}$ and an $\mathrm{IC}_{50}$ of $284.55 \mathrm{nM}$. The $\mathrm{CC}_{50}$ was $280.71 \mathrm{nM}$ for the uninfected sample. The dotted line indicates untreated virus-infected cell controls and the dashed line indicates untreated, uninfected cell controls. Error bars indicate standard deviation of the mean values obtained from triplicate samples (O'Keefe et al. 2015).

of bacteriophages' serine integrases acting in plant and mammalian cells. A co-transformation plasmid system was utilized for in vitro evaluation of different integrases in Arabidopsis thaliana protoplasts, bovine fibroblasts, and human cells. The first plasmid contained the codon-optimized integrase 2 gene and integrase 5 gene sequences under inducible promoters. The second plasmid was a reporter plasmid that contains the $g f p$ gene under the 35SCaMV promoter placed in reverse complement orientation and flanked by the attB and attP sites of both integrases. Once the integrases were expressed, the promoter sequence was flipped to its correct orientation, promoting GFP (green fluorescent protein) expression. The results obtained demonstrated that the promoter was correctly flipped, which, in turn, led to RNA polymerase flux through the DNA molecule and GFP expression, as detected by fluorescence microscopy and flow cytometry. The promoter 
inversion was detected by PCR and sequencing analyses. We anticipate our results to be an initial point for development of more complex models of gene regulation in plants using synthetically engineered integrases. Currently, we have been utilizing recombinases, such as serine integrases, to determine the endogenous nonessential genes within genomes. This fact may allow to design and provide systems to control endogenous and exogenous gene regulation through the development of synthetic genetic circuits, which, through external chemical, physical and biological inducers, are capable of switching specific traits "on" and "off" in model eukaryotic organisms (Coelho et al. 2017; Figure 4).

\section{Integrases Plasmids}

a

b
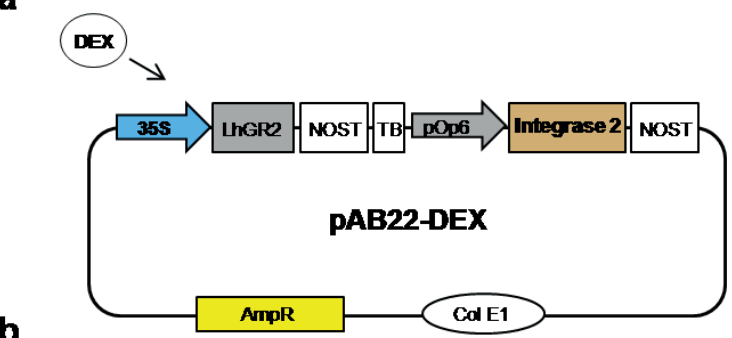
ETOH

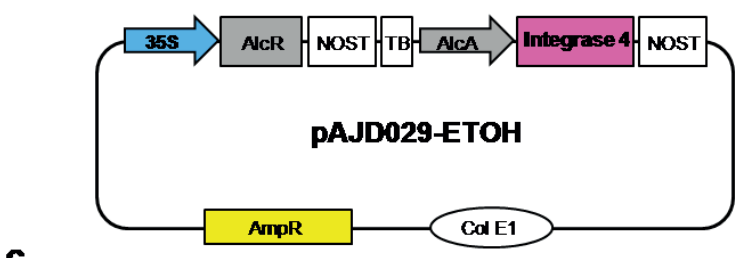

C

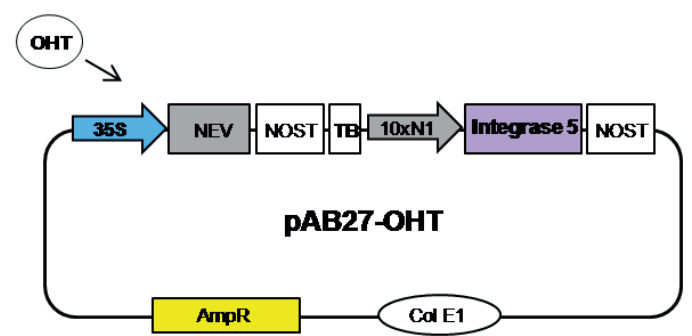

In addition to the efforts made to conserve biodiversity, an effective increase in estimates of the value of biodiversity is needed, based on evidence. The use of biotechnology may constitute a valuable tool and viable option for the advocated evaluation of biodiversity as well as for its sustainable use and production of innovative molecules. Biotechnology aiming the synthetic domestication of useful traits may well fit as a virtuous circle option. Due to the urgency and strategic importance, the operational evaluation of biodiversity should be associated with the establishment of partnerships between the public and private sectors, along with necessary interactions with developed countries as a relevant foundation.

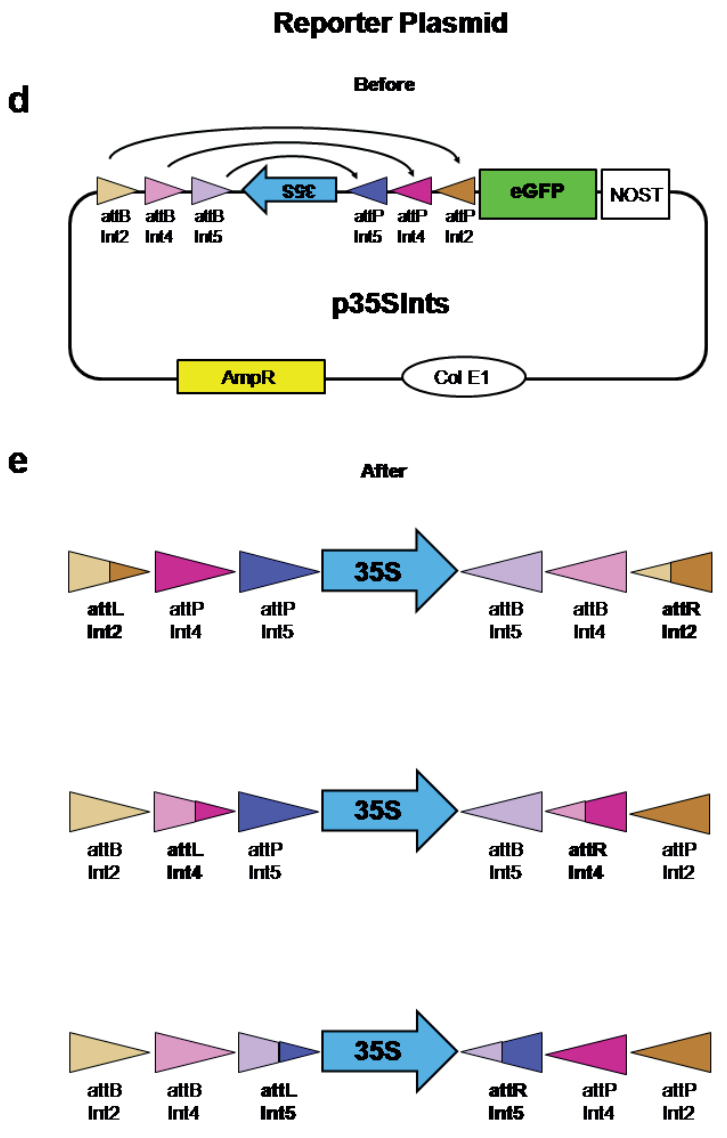

Figure 4 - Diagram of in silico design of a genetic circuit. Representation of the two plasmid system used to evaluate the functionality of the integrases in plant cells. Integrase plasmids containing two different Arabidopsis thaliana codon-optimized integrases under inducible promoters and the reporter plasmid containing eGFP under a CaMV 35S promoter at the reverse orientation and flanked by the recognition sites of the integrases, before induction and at forwarding orientation after induction (Coelho et al. 2017). 


\section{REFERENCES}

ANNALURU N ET AL. 2014. Total Synthesis of a Functional Designer Eukaryotic Chromosome. Science 344: 55-58.

ARBER W. 2012. Genetic variation and Molecular Darwinism. In: Meyers RA (Ed), Systems biology: advances in molecular biology and medicine. Verlag: Wiley-VCH, p. $145-168$

BITTENCOURT D, DITTMAR K, LEWIS RV AND RECH EL. 2010. MaSp2-like gene found in the Amazon mygalomorph spider Avicularia juruensis. Comp Biochem Physiol B Biochem Mol Biol 155: 419-426.

BOCH J, SCHOLZE H, SCHORNACK S, LANDGRAF A, HAHN S, KAY S, LAHAYE T, NICKSTADT A AND BONAS U. 2009. Breaking the Code of DNA Binding Specificity of TAL-Type III Effectors. Science 326: 15091512 .

BONNET J YIN P, ORTIZ ME, SUBSOONTORN P AND ENDY D. 2013. Amplifying genetic logic gates. Science 340: 599-603.

BOYD MR ET AL. 1997. Discovery of cyanovirin-N, a novel human immunodeficiency virus-inactivating protein that binds viral surface envelope glycoprotein gp120, potential applications to microbicide development. Antimicrob Agents Chemother 41: 1521-1530.

CARLSON DF AND LANCTO CA. 2016. Production of hornless dairy cattle from genome-edited cell lines. Nature Biotechnol 34: 479-481.

CERMAK T, DOYLE EL, CHRISTIAN M, WANG L, ZHANG Y, SCHMIDT C, BALLER JA, SOMIA NV, BOGDANOVE AJ AND VOYTAS DF. 2011. Efficient design and assembly of custom TALEN and other TAL effector-based constructs for DNA targeting. Nucl Acid Res 39: e82.

COELHO CM, GOMIDE MS, NESRALLA LR, BARROS LMG, MURAD AM AND RECH EL. 2017. Integrases target elements for DNA inversion resulting gene regulation in plant protoplasts. DOI $10.17605 / \mathrm{http}: / / \mathrm{OSF}$. IO/PBZCF | ARK c7605/osf.io/pbzcf.

CONG L ET AL. 2013. Multiplex genome engineering using CRISPR/Cas systems. Science 339: 819-823.

DARWIN C. 1868. The Variation of Animals and Plants Under Domestication. London, UK: John Murray.

DARWIN C. 1876. The Origin of Species by Means of Natural Selection, or the Preservation of Favoured Races in the Struggle for Life. London, UK: John Murray.

DOUDNA JA AND CHARPENTIER E. 2014. The new frontier of genome engineering with CRISPR-Cas9. Science 346(6213): 10.1126/science.1258096.

DOYON Y, VO TD, MENDEL MC, GREENBERG SH, WANG J, XIA DF, MILLER JC, URNOV FD, GREGORY PD AND HOLMES MC. 2011. Enhancing zinc-finger- nuclease activity with improved obligate heterodimeric architectures. Nat Methods 8: 74-79.

ESSEX M. 1996. Retroviral vaccines: challenges for the developing world. AIDS Res Hum Retrov 12: 361-363.

GARTNER SP, MARKOVITS DM, KAPLAN MH, GALLOR RC AND POPOVIC M. 1986. The role of mononuclear phagocytes in HTLV-III/LAV infection. Science 233: 215219.

GIBSON DG ET AL. 2008. Complete chemical synthesis, assembly, and cloning of a Mycoplasma genitalium genome. Science 319: 1215-1220.

GIBSON DG ET AL. 2010 Creation of a bacterial cell controlled by a chemically synthesized genome. Science 329: $52-56$

GULLISON RE, FRUMHOFF PC, CANADELL JG, FIELDM CB, NEPSTAD DC AND HAYHOE K. 2007. Tropical forests and climate policy. Science 316: 985-986.

HUTCHISON III CA ET AL. 2016. Design and synthesis of a minimal bacterial genome. Science 351: aad6253.

ISAAA. 2016.. Global Status of Commercialized Biotech/GM Crops: 2016. ISAAA Brief No. 52. ISAAA: Ithaca, NY. ISBN: 978-1-892456-66-4

JIANG W, ZHOU H, BI H, FROMM M, YANG B AND WEEKS DP. 2013. Demonstration of CRISPR/Cas9/ sgRNA-mediated targeted gene modification in Arabidopsis, tobacco, sorghum and rice. Nucl Acid Res 41: e188.

LEWIS RV. 2006. Spider silk: Ancient ideas for new biomaterials. Chem Rev 106: 3762-3774.

LI J-F ET AL. 2013. Multiplex and homologous recombination-mediated genome editing in Arabidopsis and Nicotiana benthamiana using guide RNA and Cas9. Nature Biotechnol 31: 688-691.

MALI P, YANG' KEVIN L, ESVELT M, AACH J, GUELL M, DICARLO JE, NORVILLE JE AND CHURCH GM. 2013. RNA-Guided human genome engineering via Cas9. Science 339: 823-826.

MC ELROY D. 2003. Sustaining agbiotechnology through lean times. Nature Biotechnol 21: 996-1002.

MC ELROY D. 2004. Valuing the product development cycle in agricultural biotechnology - what's in a name. Nature Biotechnol 22: 817-822.

MENDEL G. 1866. Versuche uber Pflanzen-Hybriden. Journal of Hereditary 42: 3-47.

MENDEL G. 1870. On Hleraclum-hybrids obtained by artificial fertilisation (English translation). In: Stern C, Sherwood ER (Eds), The origin of genetics: a Mendel source book, 1966. W. H. Freeman, San Francisco, p. 4955

MENDEL G. 1950. Gregor Mendel's Letters to Carl Nägeli. Genetics 35(5, pt 2): 1-29 (Originally published as: Abhandlungen der Mathematisch-Physischen Klasse der Königlich Sächsischen Gesellschaft der Wissenschaften 
29: 189-265, 1905. Reprinted in "Carl Correns, Gesammelte Abhandlungen zur Vererbungswissenschaft aus periodischen Schriften" 1899-1924. (Fritz V. Wettstein Ed.) Berlin, Julius Springer 1924: 1237-1281.

MERRY FD, AMACHER GS, LIMA E AND NEPSTAD DC. 2003. A risky forest policy in the Amazon? Science 299: 21.

MURAD AM AND RECH EL. 2011. Molecular dynamics simulations of the minor ampullate spidroin modular amino acid sequence from Parawixia bistriatra: insights into silk tertiary structure and fibre formation. J Mol Model 17: 1183-1189.

NANDAGOPAL N AND ELOWITZM B. 2011. Synthetic Biology: Integrated Gene Circuits. Science 333: 12441248.

NEPSTAD D ET AL. 2002. Frontier Governance in Amazonia. Science 295: 629-631.

NEPSTAD D, STICKER CM AND ALMEIDA OT. 2006 a. Globalization of the Amazon Soy and Beef Industries: Opportunities for Conservation. Conserv Biol 20: 15951603.

NEPSTAD D ET AL. 2006b. Inhibition of Amazon Deforestation and Fire by Parks and Indigenous Lands. Conserv Biol 20: 65-73.

NIELSEN AAK, DER BS, SHIN J, VAIDYANATHAN P, PARALANOV V, STRYCHALSKI EA, ROSS D, DENSMORE D AND VOIGT CA. 2016. Genetic circuit design information. Science 352(6281) 10.1126/science. aac7341.

O'KEEFE B ET AL. 2009. Scaleable manufacture of HIV-1 entry inhibitor griffithsin and validation of its safety and efficacy as a topical microbicide component. Proc Natl Acad Sci U S A 106: 6099-6104.

O'KEEFE BR ET AL. 2015. Engineering soya bean seeds as a scalable platform to produce cyanovirin-N, a non-ARV microbicide against HIV. Plant Biotechnol J 13: 884-892.

PERES CA AND TERBORGH JW. 1995. Amazonian nature reserves: an analysis of the defensibility status of existing conservation units and design criteria for the future. Conserv Biol 9: 34-46.

POKHILKO A, ZHAO J, STARK WM, COLLOMS SD AND EBENHOH O. 2017. A simplified mathematical model of directional DNA site-specific recombination by serine integrases. J R Soc Interface 14: 20160618.

PROSDOCIMI F, BITTECONCOURT D, DA SILVA FR, KIRST M, MOTTA PC AND RECH EL. 2011. Spinning gland transcriptomics from two main clades of spiders (order: Araneae) - insights on their molecular, anatomical and behavioral evolution. PLoS One 6(6): e21634.

RECH EL. 2017. Design of Novel Regulatory Gene Circuits in Plant Cells using Recombinase Serine Integrases.
Pontifical Academy of Science, Scripta Varia, volume 137' and Rech, available at <http://www.casinapioiv.va/content/ accademia/en/publications/scriptavaria/cellbiology.html >.

RECH EL AND ARBER W. 2013. Biodiversity as a source for synthetic domestication of useful specific traits. Ann Appl Biol 162: 141-144.

RECH EL, VIANNA GR AND ARAGAO FJ. 2008. Highefficiency transformation by biolistics of soybean, common bean and cotton transgenic plants. Nat Protoc 3: 410-418.

SCHWARTZMAN S, MOREIRA AG AND NEPSTAD DC. 2000. Rethinking tropical forest conservation: perils in parks. Conserv Biol 14: 1351-1357.

SCHWILLE P. 2011. Bottom-Up Synthetic Biology: Engineering in a Tinkerer's World. Science 333: 12521254.

SILVA LP AND RECH EL. 2013. Unravelling the biodiversity of nanoscale signatures of spider silk fibres. Nature Communications 4: 3014. DOI:10.1038/ncomms4014.

SOARES-FILHO BS ET AL. 2006. Modelling conservation in the Amazon basin. Nature 440: 520-523.

STERN N. 2006. The Economics of Climate Change: the Stern Review. Cambridge University Press, Cambridge, available at <www.hm-treasury.gov.uk/independent reviews/stern_review_economics_climate_change/stern review_report.cfm>.

TEULE F, COPPER AR, FURIN WA, BITTENCOURT D, RECH EL, BROOKS A AND LEWIS RVA. 2009. A protocol for the production of recombinant spider silk-like proteins for artificial fiber spinning. Nat Protoc 4: 341355.

WATSON JD AND CRICK FHC. 1953a. Molecular structure of nucleic acids. A structure for deoxyribose nucleic acid. Nature 171: 737-738.

WATSON JD AND CRICK FHC. 1953b. The structure of DNA. Cold Spring Harbor Symposium Quantitative Biology 18: 123-131.

WEINBERG BH, HANG PHAM NT, CARABALLO LD, LOZANOSKI T, ENGEL A, BHATIA S AND WONG WW. 2017. Large-scale design of robust genetic circuits with multiple inputs and outputs for mammalian cells. Nat Biotechnol 35: 453-462.

YANG L, NIELSEN AAK, FERNANDEZ-RODRIGUEZ J, MCCLUNE CJ, LAUB MT, LU TK AND VOIGT CA. 2014. Permanent genetic memory with $>1$-bute capacity. Nat Methods 11: 1261-1266.

YU W, LAMB JC, HAN F AND BIRCHLER JA. 2006. Telomere-mediated chromosomal truncation in maize. Proc Natl Acad Sci U S A 103: 17331-17336. 